\title{
Effects of mussels on nutrient cycling and bioseston in two contrasting tropical freshwater habitats
}

\author{
Alexandra Zieritz $(\mathbb{D})$ Farah Najwa Mahadzir • Wei Ning Chan • \\ Suzanne McGowan
}

Received: 9 August 2018/Revised: 4 March 2019/Accepted: 18 March 2019/Published online: 15 April 2019

(C) The Author(s) 2019

\begin{abstract}
Freshwater mussels (Unionida) can strongly affect nutrient cycling in temperate ecosystems but data from the tropics is lacking. We quantified the effects of mussel filtration, excretion and biodeposition on nutrient and photosynthetic pigment concentrations in a tropical eutrophic lake and mesotrophic river, featuring one non-native and two native species, respectively. Changes in nutrient and pigment concentrations were measured over a $3 \mathrm{~h}$ period to assess effects on (1) the water column in field enclosures, and (2) water column and benthos combined in controlled laboratory experiments. In field enclosures in both systems, mussel density and biomass were significantly correlated with the magnitude of reduction in sestonic pigment concentrations. In laboratory experiments, presence of mussels led to reduced $\mathrm{PO}_{4}$ and increased TAN concentrations in both systems, lower combined sestonic and deposited pigment concentrations in the river but increases in the
\end{abstract}

Handling editor: Manuel Lopes Lima

A. Zieritz $(\bowtie) \cdot$ F. N. Mahadzir · W. N. Chan Faculty of Science, School of Environmental and Geographical Sciences, University of Nottingham Malaysia Campus, Jalan Broga, 43500 Semenyih, Selangor, Malaysia

e-mail: Alexandra.zieritz@ nottingham.edu.my

A. Zieritz $\cdot$ S. McGowan

School of Geography, University of Nottingham,

Nottingham, UK same in the lake. We conclude that excretion by mussels probably accelerated bioseston growth in both systems due to $\mathrm{N}$-fertilisation, an effect that may be particularly common in tropical freshwaters, which are frequently N-limited. However, whilst river mussels reduced bioseston concentrations through rapid filtration, higher rates of $\mathrm{N}$-excretion and/or deposition of undigested bioseston by lake mussels apparently resulted in a net increase of pigment concentrations.

Keywords Bivalves - Filtration - Functional ecology $\cdot$ Nutrient cycling $\cdot$ Sinanodonta woodiana . Unionida

\section{Introduction}

Freshwater mussels (Bivalvia: Unionida, hereafter mussels) are sedentary, benthic molluscs, that feed primarily through filter-feeding and can occur in high densities in various freshwater habitats globally (Graf \& Cummings, 2015). Their filtering activity, which has been assessed to attain between about $0.1-31 \mathrm{~h}^{-1}$ mussel $^{-1}$ (Kryger \& Riisgård, 1988; Chowdhury et al., 2016; Cyr et al., 2017 and references therein), affects ecosystems at various trophic levels and compartments (Vaughn et al., 2008). Firstly, mussels affect seston abundance and composition in the water column by removing organic and inorganic particles, 
including phytoplankton, zooplankton and bacteria (Christian et al., 2004; Howard \& Cuffey, 2006; Spooner \& Vaughn, 2006 and references therein). High mussel densities can result in increased water clarity, affecting growth and community composition of plankton and macrophytes (Welker \& Walz, 1998; Chowdhury et al., 2016; Vaughn, 2018). At the same time, mussels excrete nutrients as solutes (predominantly $\mathrm{NH}_{3}$ and $\mathrm{PO}_{4}$ ) to the water column, thereby providing nutrients for primary producers (Nalepa et al., 1991). Mussel excretion generally increases the $\mathrm{N}: \mathrm{P}$ ratio, which can alleviate strict $\mathrm{N}$-limitation in streams and can lead to a subsequent change in algal communities (Atkinson et al., 2013).

Mussels also affect nutrient concentrations and composition of the sediment by biodeposition. Whilst ingested edible material and part of the nutrients are assimilated and converted into soft tissue and shell, much of the material taken up from the water column is deposited to the sediment as non-assimilated pseudofaeces and egested faeces (Howard \& Cuffey, 2006; Spooner \& Vaughn, 2006; Saraiva et al., 2011). Biodeposition of faeces and pseudofaeces results in an increased availability of nutrients (particularly $\mathrm{N}$ and P) and other resources for benthic organisms, which in turn enhances benthic production and biodiversity (Howard \& Cuffey, 2006). In addition, at least some species and populations of freshwater mussels have been shown to not exclusively feed on seston but exhibit a much more diverse diet including benthic algae and allochthonous organic material of terrestrial origin (James, 1987; Nichols \& Garling, 2000; Raikow \& Hamilton, 2001; Collier et al., 2017; Zhang et al., 2017).

Much of the research on the effect of mussel filtration, excretion and deposition on suspended algae (measured as pigments) and nutrient concentrations has been conducted in controlled ex situ experiments. Clearance rates have been estimated for a number of species by measuring the decline in chlorophyll a (chl a) concentrations after mussel filtration as a proxy for rates of phytoplankton removal from the water column (e.g., Kryger \& Riisgård, 1988; McIvor, 2004; Chowdhury et al., 2016). Clearance rates, excretion rates, deposition rates and quality of excretion and deposition products (e.g., N:P ratios) vary with species, size and reproductive stage of mussels, food, temperature and other environmental conditions (see Vaughn et al., 2008 for a comprehensive list of references). For example, mussel populations from fast flowing rivers have been found to be more efficient in clearing phytoplankton from the water column than those from slow flowing rivers or lentic systems (Byllaardt \& Ackerman, 2014).

Whilst controlled laboratory experiments are useful in determining mussel clearance, excretion and deposition rates, field- or semi-natural experiments are needed to understand the in situ effects of freshwater mussels on their environment. Vaughn et al. (2004) used controlled mesocosm experiments to assess how mussel density and species composition affects TAN (= total ammonia nitrogen $\left.=\mathrm{NH}_{3}+\mathrm{NH}_{4}\right)$ and chl a concentrations in the water column. TAN concentrations increased with mussel density as expected, but so did chl a due to a TAN-fertilisation effect. In contrast, Soto \& Mena (1999) showed that Diplodon chilensis (Gray, 1852) significantly reduced water columnconcentrations of chl a ( $\sim$ tenfold in 18 days), TAN ( $\sim$ fourfold), SRP (soluble reactive phosphorus; $\sim$ fourfold) and TP (total phosphorus; $\sim$ tenfold) in outdoor fish tanks compared to tanks without mussels. Depending on the ecosystem and characteristics of dominant species present, the effects of freshwater mussels on nutrient cycling and phytoplankton production can thus be highly variable, from reducing nutrient loadings to stimulating primary production where nutrients are limiting by converting suspended material to dissolved nutrients (Vaughn et al., 2007). For example, the effect of mussels on nutrient cycling of lotic systems has been shown to be much stronger under low discharge compared to high discharge conditions (Vaughn, 2018).

Data on freshwater mussel filtration, excretion and biodeposition published to date are almost exclusively restricted to temperate systems. Nutrient cycling in tropical freshwaters differs considerably from that in temperate ones, owing to consistently high temperatures and strongly seasonal patterns in river discharge, water depth, conductivity, and concentrations of oxygen and nutrients (Winemiller \& Jepsen, 2005). In comparison with temperate rivers, tropical freshwaters are characterised by much higher sediment load and are more frequently N-limited, resulting in greatly increased primary production when pristine tropical lands are disturbed (Downing et al., 1999). In small tropical streams, benthic organisms and food resources are frequently diminished by flash floods that scour the substrate (Winemiller \& Jepsen, 2005). 
Filtration rates and effects of mussel feeding on tropical ecosystems may therefore be expected to differ from those in temperate systems. At the same time, understanding the functional role and importance of biota in tropical ecosystems is particularly important when considering the high rates and extent of species loss in these systems (Dudgeon et al., 2006; Cumberlidge et al., 2009). Despite these facts, we are aware of only a single study on the effects of tropical freshwater mussels, which determined ex situ chl a clearance rates of two Unionidae species collected from an urban lake in Bangladesh (Chowdhury et al., 2016).

The present study aims to assess the effects of mussel filtration, excretion and deposition on nutrient and bioseston concentrations in two tropical ecosystems; a natural river and an artificial lake in Peninsular Malaysia.

\section{Methods}

Study sites

Semenyih Lake is a small, shallow, eutrophic artificial lake $\left(\right.$ max depth $\sim 2 \mathrm{~m}$, total area $\sim 0.05 \mathrm{~km}^{2}$ ) located close to a residential area and used for fishing and other recreational activities (Table 1). Muar River is a mesotrophic river ( $\sim 7-11 \mathrm{~m}$ wide) that flows through a mosaic of oil palm plantation and secondary forest, several $\mathrm{km}$ from the nearest human settlement (Table 1). The only mussel present in the lake is the non-native Sinanodonta woodiana Lea, 1834, which is native to China and Russia, and has been widely introduced in ponds and rivers across Malaysia (Watters, 1997; Zieritz et al., 2016, 2018b). The river features two native mussel species, Contradens contradens (Lea, 1838) and Monodontina vondembuschiana (Lea, 1840) (Zieritz et al., 2016).

\section{Experimental setup}

We conducted two experiments that were designed to assess the effects of freshwater mussels on their environment in semi-natural conditions: (1) The relationship between mussel density/biomass and changes in nutrient and photosynthetic pigment concentrations in the water column was assessed in field experiments at the two study sites at Semenyih Lake and Muar River (Table 1). (2) Effects of mussel filtration, excretion and deposition on the water column and benthos combined were assessed in laboratory experiments using mussels and water collected from the two study sites.

\section{Field experiments}

Field experiments were carried out over four days in the dry season in July 2015 (Muar River) and March 2016 (Semenyih Lake), respectively. Each day, at each of the two study sites, three black, bottomless, open plastic cylinders $($ diameter $=43 \mathrm{~cm}$, height $=51 \mathrm{~cm}$ ) were placed at randomly selected spots across a 100-m stretch of river/lake where mussels were present, at a maximum of 3-m distance from the shore where the water level was $<40 \mathrm{~cm}$ and the tops of the cylinders were therefore above water column. Mussels were not disturbed, and mussel density was not manipulated to provide as natural conditions as possible. Water depth was measured in each cylinder. Water samples $\left(\begin{array}{ll}1 & 1\end{array}\right)$ were taken from each of the cylinders at $50 \%$ of water depth at the beginning of the experiment and again after $3 \mathrm{~h}$. This corresponds to water before mussel filter-feeding activity and after filter-feeding activity takes place, respectively. After the filtration period, all the mussels from the cylinders were collected, counted and their shell length (SL) measured to $\pm 0.1 \mathrm{~cm}$ accuracy using a sliding calliper. In addition, two replicate water samples were taken per day from outside the cylinders for description of general characteristics of the study sites.

\section{Laboratory experiments}

The laboratory filtration experiments were carried out at $25^{\circ} \mathrm{C}$ air temperature at the University of Nottingham Malaysia Campus during the dry season in August (Semenyih Lake) and September 2016 (Muar River). In the morning of the day of the experiment, a total of 20 (10 C. contradens and $10 \mathrm{M}$. vondembuschiana) and 15 (for $S$. woodiana) randomly selected mussels, and approximately 801 of river/lake water were taken from each of the two sites and transported to the laboratory in darkened containers. In the laboratory, 23 and 18 (for Muar and Semenyih experiment, respectively) transparent, cylindrical, 3.61 plastic tanks were set up with 3.51 of lake water and an air stone connected to an air pump in each; no substrate was added to the tanks. A 0.51 water sample 
Table 1 Geographical coordinates, water quality parameters, and mussel species richness, density and biomass (tissue dry weight) in dry season 2015/16 at the two study sites

\begin{tabular}{|c|c|c|}
\hline & Semenyih Lake & Muar River \\
\hline Coordinates & $2.9470 \mathrm{~N}, 101.8598 \mathrm{E}$ & $2.7661 \mathrm{~N}, 102.3960 \mathrm{E}$ \\
\hline $\operatorname{chl~a~}\left(\mu \mathrm{g}^{-1}\right)$ & $16 \pm 10(5-32)(N=8)$ & $1.6 \pm 0.8(0.6-2.7)(N=8)^{* *}$ \\
\hline carotenoids $\left(\mu \mathrm{SPU} 1^{-1}\right)$ & $20 \pm 11(5-34)(N=8)$ & $6 \pm 6(1-13)(N=8)^{*}$ \\
\hline $\mathrm{TP}\left(\mu \mathrm{g} 1^{-1}\right)$ & $36 \pm 2(35-38)(N=8)$ & $46 \pm 7(35-57)(N=8)^{\text {n.s. }}$ \\
\hline $\operatorname{SRP}\left(\mu \mathrm{g}^{-1}\right)$ & $11 \pm 0.8(9-12)(N=8)$ & $39 \pm 4(33-49)(N=8) * * *$ \\
\hline TAN $\left(\mu \mathrm{g}^{-1}\right)$ & $57 \pm 29(25-102)(N=8)$ & $23 \pm 32(0-96)(N=8)^{*}$ \\
\hline $\mathrm{NO}_{3}-\mathrm{N}\left(\mathrm{mg} \mathrm{l}^{-1}\right)$ & $0.01 \pm 0.02(0-0.08)(N=8)$ & $2 \pm 0.7(1-3)(N=8)^{* * *}$ \\
\hline Species present & Sinanodonta woodiana & Contradens contradens and Monodontina vondembuschiana \\
\hline Mussels $\left(\mathrm{m}^{-2}\right)$ & $13 \pm 9(3-35)(N=12)$ & $23 \pm 14(6-50)(N=12)^{*}$ \\
\hline Mussels $\left(1^{-1}\right)$ & $0.10 \pm 0.08(0.02-0.31)(N=12)$ & $0.19 \pm 0.11(0.05-0.36)(N=12)^{*}$ \\
\hline DW m ${ }^{-2}(g)$ & $60 \pm 44(6-167)(N=12)$ & $34 \pm 17(13-67)(N=12)^{\text {n.s. }}$ \\
\hline $\mathrm{DW}^{-1}(\mathrm{~g})$ & $0.47 \pm 0.37(0.04-1.41)(N=12)$ & $0.28 \pm 0.15(0.11-0.57)(N=12)^{\text {n.s. }}$ \\
\hline SL (cm) (field) & $9.0 \pm 2.9(4.1-14.0)(N=45)$ & $5.3 \pm 1.8(2.6-5.0)(N=89)^{* * *}$ \\
\hline SL (cm) (laboratory) & $10.3 \pm 2.3(5.4-14.9)(N=20)$ & $5.2 \pm 1.5(3.0-7.7)(N=30)^{* * *}$ \\
\hline Trophic state index & 57 [eutrophic after Cunha et al. (2013)] & 35 [mesotrophic after Dodds et al. (1998)] \\
\hline
\end{tabular}

Data are presented as averages \pm standard deviation (range). Asterisks indicate significant differences between the study sites determined by Mann-Whitney $U$ test $(* P<0.05, * * P<0.01, * * * P<0.001 ;$ n.s. not significant)

chl a chlorophyll a, $D W$ mussel soft tissue dry weight, $\mathrm{NO}_{3}-\mathrm{N}$ nitrate, $S L$ shell length, $S R P$ soluble reactive phosphorus $\left(\mathrm{PO}_{4}-\mathrm{P}\right), T A N$ total ammonia nitrogen $\left(\mathrm{NH}_{4}-\mathrm{N}+\mathrm{NH}_{3}-\mathrm{N}\right), T P$ total phosphorus

was taken from each tank for analysis. Immediately afterwards, one mussel that was previously scrubbed to remove epibionts was put inside each tank with the exception of three randomly selected tanks, which served as controls. After $3 \mathrm{~h}$, mussels were removed from the tanks and water was collected after homogenisation. SL of each mussel was measured as above. Mussel soft tissue was dissected from each specimen, dried at $80^{\circ} \mathrm{C}$ for $48 \mathrm{~h}$ and weighed to $\pm 0.01 \mathrm{~g}$ accuracy.

\section{Water chemistry analysis}

Water samples were refrigerated and processed as soon as possible on the day of the experiment. A known volume of each water sample (0.2-0.4 1, depending on turbidity) was filtered through Whatman ${ }^{\circledR} \mathrm{GF} / \mathrm{C}$-filters with a vacuum pump. Filters were frozen, and filtered and unfiltered water samples were kept cool for subsequent determination of following parameters in the laboratory: Concentrations of chlorophyll a (chl a), carotenoids, total phosphorus (TP), soluble reactive phosphorus (SRP), total ammoniacal nitrogen $(\mathrm{TAN})$, and nitrate $\left(\mathrm{NO}_{3}-\mathrm{N}\right)$ were assessed using standard spectrophotometric/colorimetric methods (Lorenzen, 1967; Mackereth et al., 1989). Particulate phosphorus (PP) was subsequently estimated as $\mathrm{PP}=\mathrm{TP}-\mathrm{SRP}$.

Data analysis

\section{Comparison of study sites}

Differences in baseline conditions at the two study sites were assessed using Mann-Whitney U tests on the six water quality parameters measured from eight replicate water samples taken across the four study days, as well as mussel density, biomass and SL in the 12 replicate field cylinders. Mussel density and biomass were calculated both per area and water volume using the surface area covered by the cylinder (i.e., $1452 \mathrm{~cm}^{2}$ ) and water depth in the cylinder. Biomass per cylinder was estimated by (1) deriving the power equation of SL versus tissue dry weight for each habitat from the specimens used in the laboratory experiment; (2) applying these equations to estimate tissue dry weight for each specimen found in field cylinders based on SL measurements; and (3) 
summing together the estimated tissue dry weights of all specimens in a cylinder.

The change in concentration of the six parameters ( $\Delta$ chla, $\Delta$ carotenoids etc.) after $3 \mathrm{~h}$ incubation was determined for each replicate cylinder (field experiments) or tank (laboratory experiments) by subtracting concentrations at the beginning of the experiment from respective concentrations at the end of the experiment.

\section{Field experiments}

We assessed the effect of mussel density and biomass in field experiments using General Linear Models (GLMs) on each of the six measured parameters, fitting mussel density or biomass (tissue dry weight) as a covariate, day as a factor with three levels, and the interaction factor. Non-significant factors/covariates were sequentially removed from the model (backwards selection).

\section{Laboratory experiments}

We tested for differences in each of the six parameters between mussel ( $n=20$ and 30 for lake and river experiments, respectively) and control treatments $(n=3)$ in laboratory experiments using Welch's unequal variances $\mathrm{t}$ tests, which are more reliable than Students t tests when sample sizes are unequal (Ruxton, 2006). For the river-laboratory experiment, these were preceded by Students $t$ tests on the mussel dataset only to test for significant differences between the two river mussel species ( $n=15$ for both species). We then assessed the effect of mussel size and species (for river-laboratory experiments only) on each of the six parameters using GLMs, fitting SL or biomass (tissue dry weight) as a covariate, species as a factor with two levels (for river-laboratory experiment only), and the interaction factor. Non-significant factors/covariates were sequentially removed from the model (backwards selection).

We calculated clearance rates of chl a $\left(\mathrm{CR}_{\mathrm{chla}}\right)$ for each mussel using the formula $\ln \left(C_{0} / C_{\mathrm{t}}\right) \times V / T$, and excretion rates for TAN $\left(\mathrm{R}_{\mathrm{TAN}}\right)$ using the formula $\left(C_{\mathrm{t}}-C_{0}\right) \times V / T$, where $C_{\mathrm{t}}$ and $C_{0}$ are final and initial nutrient or pigment concentrations, respectively, $V$ is the volume of water in the tank (3l), and $T$ is incubation time $(3 \mathrm{~h})$ (following Riisgård (2001a, b) and Cyr et al. (2017)), and deducting respective rates obtained in control tanks. All statistical analyses were conducted in $\mathrm{R}$.

\section{Results}

Differences between study sites

The two study sites differed significantly in water quality parameters and other characteristics (Table 1). Lake water concentrations of chl a and TAN were significantly higher than in river water, whilst SRP and $\mathrm{NO}_{3}-\mathrm{N}$ concentrations were significantly higher in the river than the lake (Table 1). Ratios of available N/P were $\sim 5$ in the lake and $<1$ in the river.

Mussel densities in the river were significantly higher than the lake (Table 1). However, due to significantly different mussel sizes at the two habitats, mussel biomass (soft tissue dry weight) per area and volume of water did not differ significantly between the two sites (Table 1). SL within each habitat was similar in laboratory and field experiments (t tests: River: $t=0.359, \quad$ df $=117, \quad P=0.720 ; \quad$ Lake: $t=1.828, \quad \mathrm{df}=63, P=0.072$ ). The relationship between SL and dry weight of mussel tissue (DW) was DW $[\mathrm{g}]=0.043 \times \mathrm{SL}[\mathrm{cm}]^{2.158}\left(R^{2}=0.67\right)$ for lake mussels and DW $[\mathrm{g}]=0.050 \times \mathrm{SL}[\mathrm{cm}]^{1.977}$ for river mussels $\left(R^{2}=0.64\right)$; this relationship was not different between the two river species (ANCOVA: dry weight: $F=82.195, \quad P<0.0001$; Species: $F=2.080, \quad P=0.161 ; \quad$ dry $\quad$ weight $\times$ Species: $F=0.068, P=0.797)$.

Field experiments (effects on the water column)

In field experiments, mussel density had a clear effect on sestonic photosynthetic pigment concentrations, with $\Delta$ chl a and $\Delta$ carotenoid being significantly negatively correlated with mussel density in the river and lake, respectively (Fig. 1a, b). Although changes in sestonic nutrient concentrations in the water column were not significantly correlated with mussel density, $\mathrm{R}^{2}$ values $(\geq 0.15)$ indicated associations between mussel density and $\triangle \mathrm{TAN}$ at both sites, with the relationship being positive at the lake, but negative at the river (Fig. 1e). Similar but slightly weaker correlations were found with mussel biomass (Lake: $\Delta$ carotenoid: $P=0.028, R^{2}=0.40$; River: $\Delta$ chl a: $P=0.040, \quad R^{2}=0.36$; all other correlations not 

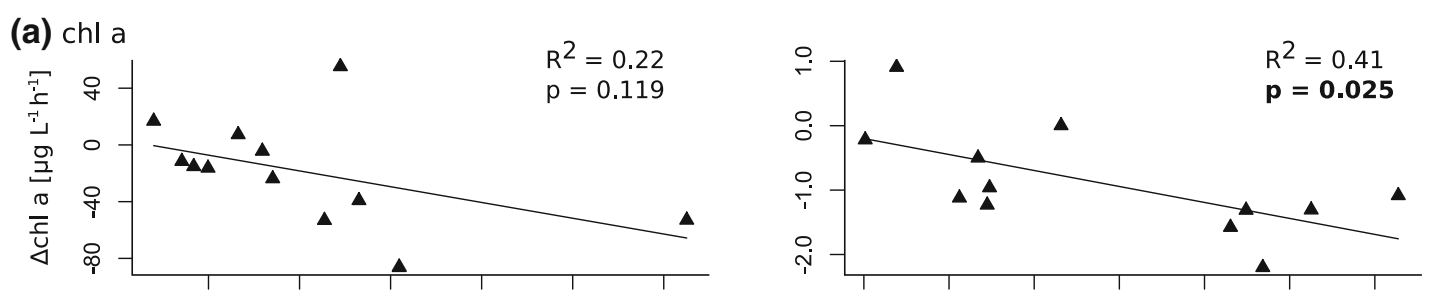

(b) carotenoids
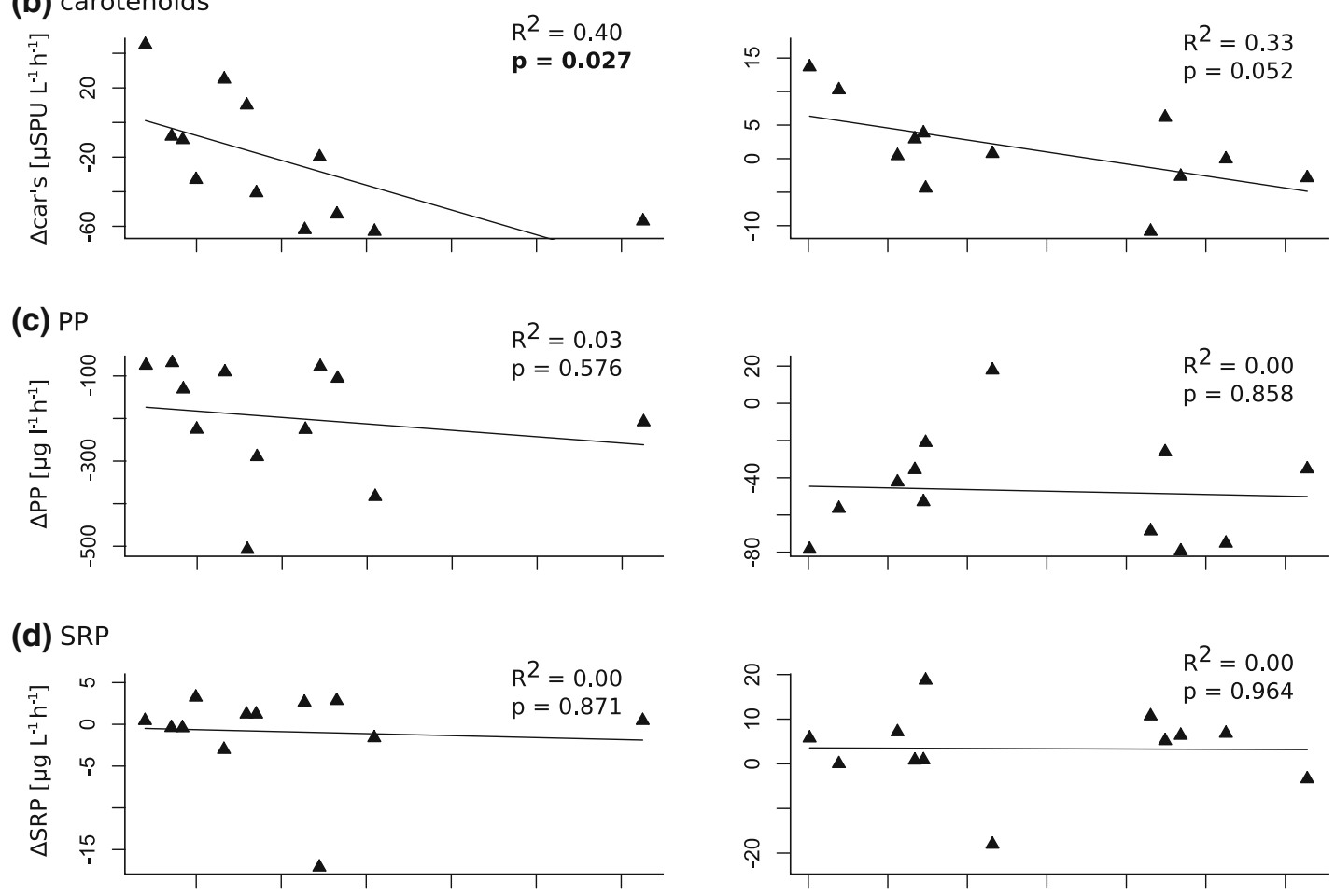

(e) TAN
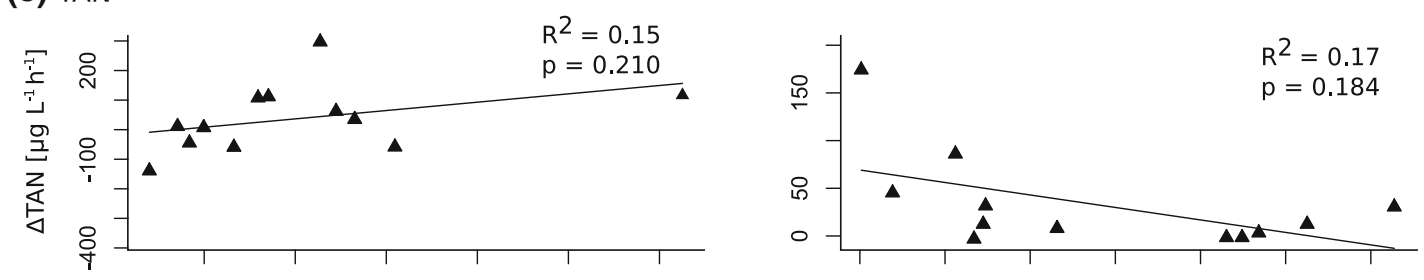

(f) $\mathrm{NO}_{3}-\mathrm{N}$
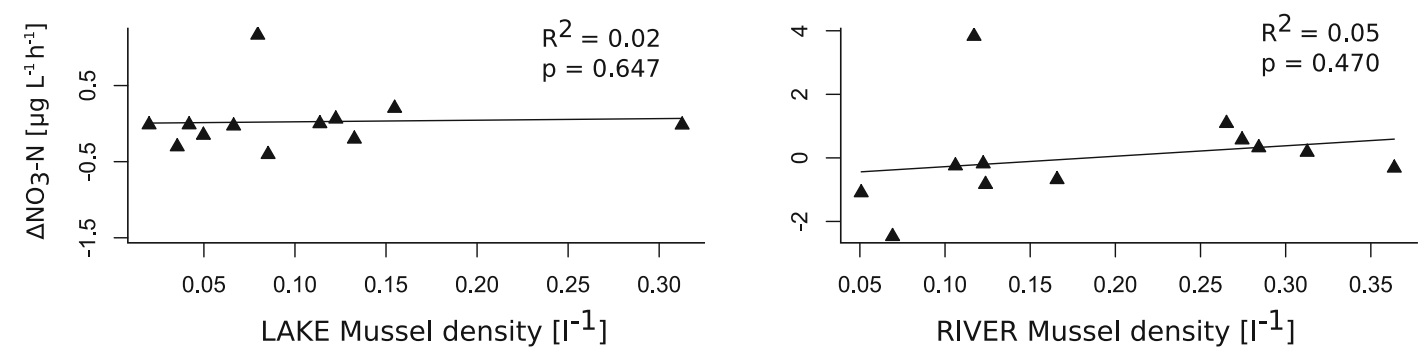
\Fig. 1 Relationship between mussel density and change in pigment and nutrient concentrations after 3-h enclosure experiments in Semenyih Lake and Muar River, Malaysia. Bold values are significant at $95 \%$ level

statistically significant). The day when the experiment was conducted did not significantly affect changes in water column pigment or nutrient concentrations in cylinders (ANOVAs: Lake: $\Delta$ chla: $F=0.849$, $P=0.505 ; \Delta$ carotenoid: $F=3.759, P=0.060 ; \Delta \mathrm{PP}$ : $F=2.309, P=0.153 ; \Delta$ SRP: $F=0.739, P=0.558$; $\Delta$ TAN: $F=0.191, \quad P=0.900 ; \Delta \mathrm{NO}_{3}: F=0.253$, $P=0.857$; River: $\Delta$ chla: $F=3.653, \quad P=0.063$; $\Delta$ carotenoid: $F=0.605, P=0.630 ; \Delta \mathrm{PP}: F=0.609$, $P=0.628 ; \quad \Delta$ SRP: $F=0.631, \quad P=0.615 ; \quad \Delta$ TAN: $\left.F=1.121, P=0.396 ; \Delta \mathrm{NO}_{3}: F=0.511, P=0.686\right)$.

Laboratory experiments (combined effects on the water column and benthos)

In laboratory experiments conducted on the lake system components, combined sestonic and deposited $\Delta$ chl a, $\Delta$ carotenoids, $\Delta \mathrm{PP}, \Delta \mathrm{TAN}$ and $\Delta \mathrm{NO}_{3}-\mathrm{N}$ was significantly larger in mussel treatments compared to controls (Table 2, Fig. 2). Mussel presence also appeared to negatively affect $\Delta \mathrm{SRP}$ though this effect was not statistically significant (Table 2, Fig. 2d). In addition, within mussel treatments, $\Delta$ chl a, $\Delta$ carotenoids, $\triangle \mathrm{PP}$ and $\Delta \mathrm{TAN}$ significantly increased with SL, whilst no significant effect was found in this respect for $\Delta \mathrm{SRP}$ and $\Delta \mathrm{NO}_{3}-\mathrm{N}$ (Fig. 3).

For laboratory experiments on the river system components, no significant differences were found between the two species $M$. vondembuschiana and $C$. contradens in univariate tests on any of the six parameters ( $t$-tests: $\Delta$ TAN: $t=0.534, P=0.598$; $\Delta \mathrm{SRP}: t=1.695, \quad P=0.101 ; \Delta \Delta \mathrm{NO}_{3}: t=1.698$, $P=0.101 ; \Delta \mathrm{PP}: t=-0.547, P=0.589 ; \Delta \mathrm{chl}$ a: $t=-0.259, \quad P=0.797 ; \quad \Delta$ caro: $\quad t=0.821$, $P=0.419)$. Data of all 30 river-mussel replicates were therefore pooled in subsequent Welch Two-Sample $\mathrm{t}$ tests, which showed that combined sestonic and deposited $\Delta$ chl a and $\Delta$ SRP decreased significantly more in mussel tanks compared to control tanks (Table 2, Fig. 2a, d). GLMs on the river-mussel dataset showed that $\triangle \mathrm{SRP}$ was significantly negatively correlated with SL in $M$. vondembuschiana but not in C. contradens (Fig. 3d). $R^{2}$ was also considerable
Table 2 Welch two sample t tests results assessing differences between mussel and control treatments in the change in concentrations of ambient pigments and nutrients after $3 \mathrm{~h}$ in Semenyih Lake and Muar River water, respectively

\begin{tabular}{clll}
\hline & $t$ & df & $P$ \\
\hline$\Delta$ chl a & & & \\
Lake & -5.4393 & 20.031 & $<\mathbf{0 . 0 0 0 1}$ \\
River & 3.6693 & 4.489 & $\mathbf{0 . 0 1 7 5}$ \\
$\Delta$ carotenoids & & & \\
Lake & -4.4606 & 5.216 & $\mathbf{0 . 0 0 6 0}$ \\
River & 0.3332 & 3.346 & 0.7588 \\
$\Delta$ PP & & & \\
Lake & -6.104 & 19.312 & $<\mathbf{0 . 0 0 0 1}$ \\
River & -2.2279 & 2.9382 & 0.1141 \\
$\Delta$ SRP & & & \\
Lake & 1.3374 & 2.318 & 0.2972 \\
River & 3.3359 & 2.799 & $\mathbf{0 . 0 4 9 3}$ \\
$\Delta$ TAN & & & \\
Lake & -8.639 & 10.541 & $<\mathbf{0 . 0 0 0 1}$ \\
River & 1.0545 & 5.221 & 0.3380 \\
$\Delta$ NO 3 -N & & & \\
Lake & 2.3173 & 7.791 & $\mathbf{0 . 0 4 5 0}$ \\
River & 0.2005 & 2.24 & 0.8579 \\
\hline Bold & & &
\end{tabular}

Bold values are significant at $95 \%$ level

(0.10) for the positive association between mussel SL and $\Delta \mathrm{PP}$ (Fig. $3 \mathrm{c})$. This trend was in accordance with a distinctly higher average $\Delta \mathrm{PP}$ in mussel compared to control treatments (Fig. 2c). Similar correlations were found with mussel biomass (Lake: $\Delta$ chl a: $P=0.001$, $R^{2}=0.45, \Delta$ carotenoid: $P=0.008, R^{2}=0.33, \Delta \mathrm{PP}$ : $P=0.0001, R^{2}=0.57, \Delta \mathrm{TAN}: P<0.0001, R^{2}=$ 0.72; River: $\triangle$ SRP: $C$. contradens: $P=0.285, R^{2}=$ $0.09, M$. vondembuschiana: $P=0.035, R^{2}=0.28$; all other correlations not significant).

Excretion rates of TAN per mussel differed considerably between systems. One lake mussel on average excreted $17 \times$ as much TAN as a river mussel (lake: $\quad 51 \pm 21 \mu \mathrm{g} \mathrm{N}$ mussel $^{-1} \mathrm{~h}^{-1}$; river: $3 \pm 7 \mu \mathrm{g} \mathrm{N}^{\text {mussel }}{ }^{-1} \mathrm{~h}^{-1}$ ), and about $5 \times$ as much when accounting for differences in mussel size between the two ecosystems (i.e., weight-corrected excretion rates calculated based on average DW of $5.4 \mathrm{~g}$ and $1.5 \mathrm{~g}$ DW for lake and rivers mussels, respectively: lake: $9.4 \mu \mathrm{g} \mathrm{N} \mathrm{g} \mathrm{DW}^{-1} \mathrm{~h}^{-1}$; river: $2.0 \mu \mathrm{g} \mathrm{N} \mathrm{g} \mathrm{DW}{ }^{-1} \mathrm{~h}^{-1}$ ). Considering that average densities were 0.47 and $0.28 \mathrm{~g} \mathrm{DW}^{-1}$ in the lake and 
(a) chl a

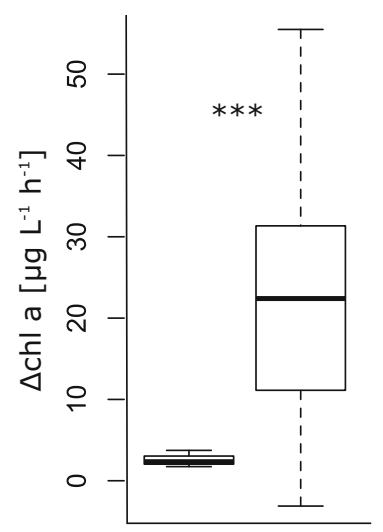

(c) PP

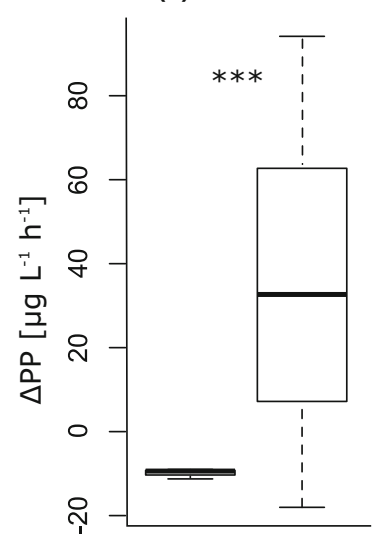

(e) TAN

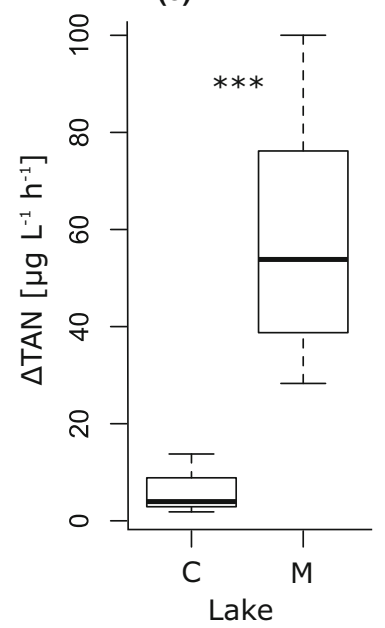

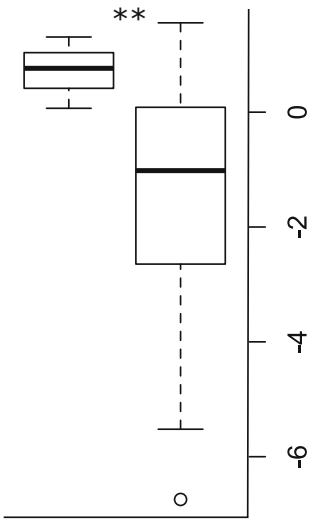
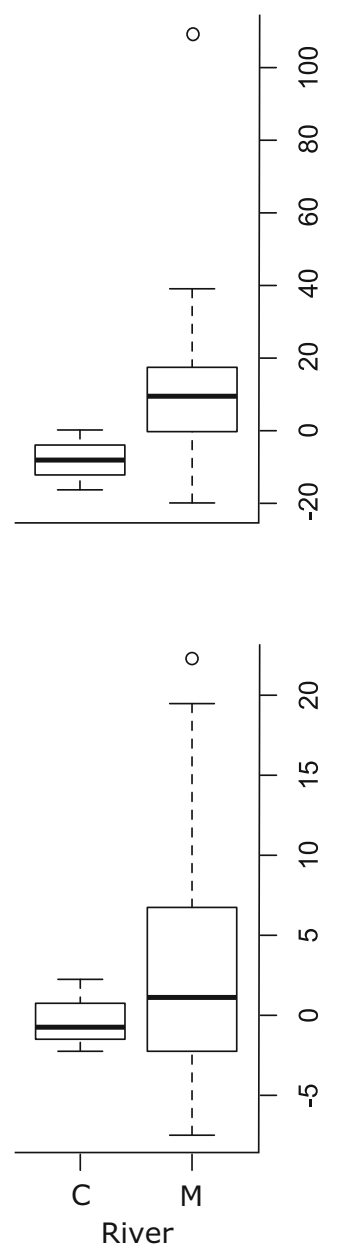

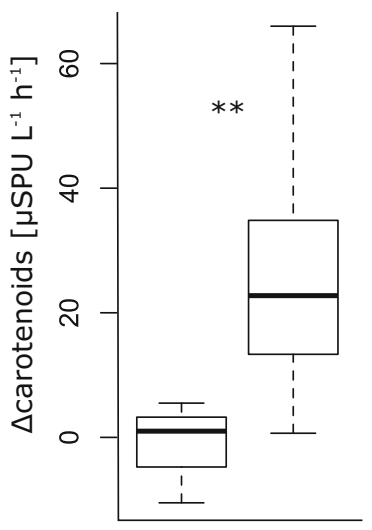

(d) SRP

(b) carotenoids

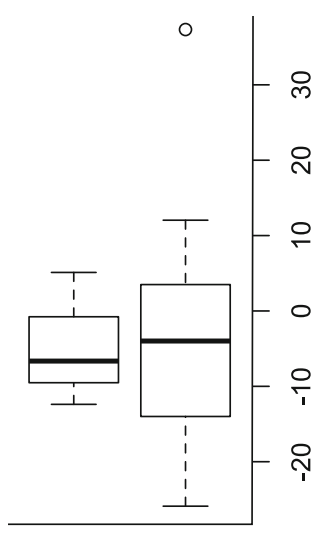

(d) SRP
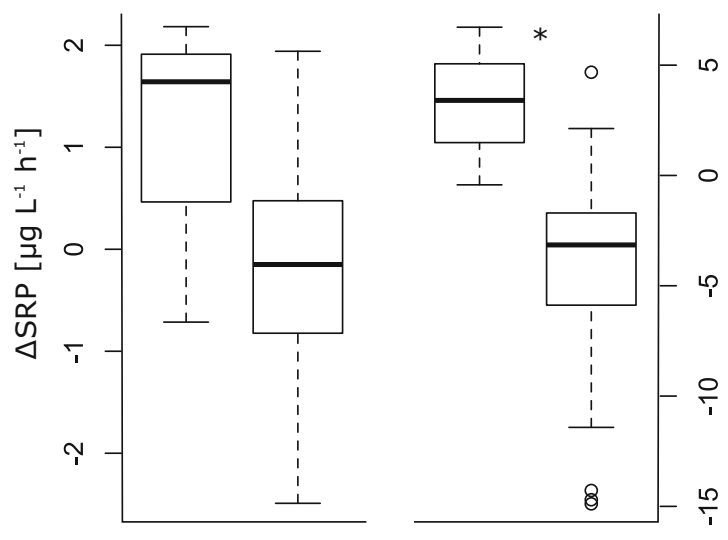

(f) $\mathrm{NO}_{3}-\mathrm{N}$

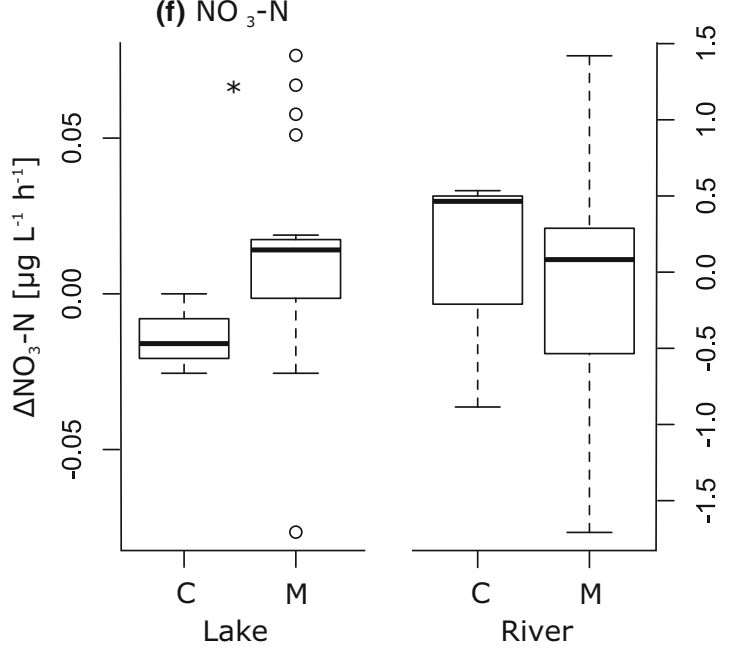


4 Fig. 2 Boxplots of change in pigment and nutrient concentrations after $3 \mathrm{~h}$ in 31 of lake/river water with single mussels $(M$; $n=20$ for lake, $n=30$ for river) and without mussels $(C$; $n=3$ ). Box limits represent third and first quartile; centre horizontal line represents median; vertical lines represent maximum and minimum; dots represent outliers. Asterisks indicate significant differences between control and mussel tanks determined by Welch Two-Sample t tests $\left({ }^{*} P<0.05\right.$, $* * P<0.01, * * * P<0.001 ;$ n.s. not significant). Note that boxplots and $y$-axis on the left refer to the lake habitat, whereas those on the right refer to the river

river, respectively (Table 1), mussels excrete about $4.4 \mu \mathrm{g} \mathrm{N}^{-1} \mathrm{~h}^{-1}$ in the lake and $0.56 \mu \mathrm{g} \mathrm{N}^{-1} \mathrm{~h}^{-1}$ in the river system.

$\mathrm{CR}_{\text {chla }}$ averaged $0.81 \mathrm{mussel}^{-1} \mathrm{~h}^{-1}$ for $C$. contradens and 1.01 mussel $^{-1} \mathrm{~h}^{-1}$ for $M$. vondembuschiana, reaching a maximum of 3.21 mussel $^{-1} \mathrm{~h}^{-1}$ in the river. $\mathrm{CR}_{\text {chla }}$ for $S$. woodiana was negative, averaging -0.91 mussel $^{-1} \mathrm{~h}^{-1}$.

\section{Discussion}

Increasing TAN concentrations by excretion

Laboratory experiments showed that excretion by both lake and river mussels increased TAN concentrations. Compared to previously reported values, which range from excretion of about 4-80 $\mu \mathrm{g} \mathrm{N}$ mussel ${ }^{-1} \mathrm{~h}^{-1}$ or 5-80 $\mu \mathrm{g} \mathrm{N} \mathrm{g} \mathrm{DW}^{-1} \mathrm{~h}^{-1}$ (Nalepa et al., 1991; Baker \& Hornbach, 2001; Vaughn et al., 2004; Cyr et al., 2017), TAN excretion rates reported in the present study were moderate to low for Semenyih Lake and very low for Muar River. Lake mussels excreted $17 \times$ more TAN on average compared to river mussels, and almost $5 \times$ more when accounting for size differences. TAN excretion rates of lake mussels are probably underestimations, as suggested by the significant increase in $\mathrm{NO}_{3}-\mathrm{N}$ concentrations in tanks with mussels compared to controls. It is likely that this increase arises from nitrification of the $\mathrm{NH}_{4}$ excreted by $\mathrm{S}$. woodiana, which may have been amplified by aeration during the experiment and explains the lack of correlation between $\mathrm{NO}_{3}-\mathrm{N}$ and mussel size (Lewis, 2001). $S$. woodiana in the lake thus exhibits much higher TAN excretion rates than the two native study species in the river, even after accounting for size differences between the species (Fig. 3e). We cannot distinguish whether the observed difference in TAN excretion rates was caused by differences in seston quantity and quality between sites, by a species-effect, or a combination of the two, but mass-specific TANexcretion rates have been observed to differ by up to $>3$ times even between sympatric freshwater mussel species (Spooner \& Vaughn, 2008).

\section{$\mathrm{N}$-fertilisation accelerates bioseston growth}

Both study systems were N-limited, with soluble N/P ratios considerably lower than the Redfield ratio. Data from our laboratory experiments indicate that TAN excretion by mussels alleviated this $\mathrm{N}$-limitation and stimulated bioseston growth in both systems. That is, a pronounced decrease in SRP concentrations was observed in mussel tanks compared to control tanks for both the lake and the river system (Fig. 2d). This decrease was unexpected as freshwater mussels are known to excrete SRP (Nalepa et al., 1991; Vaughn et al., 2004) but may be explained by increased growth of bioseston and consequently, increased SRP uptake, in mussel tanks due to increased TAN availability. A similar TAN-fertilisation effect by mussels leading to increased bioseston growth (detected as increased chl a concentrations) has been observed previously in a mesocosm study by Vaughn et al. (2004).

Despite N-fertilisation, for the river-derived laboratory experiments, chl a concentrations decreased significantly in the presence of mussels, suggesting that phytoplankton was rapidly taken up by mussels and passed into their digestive system. The lack of a significant reduction in carotenoid concentrations in mussel treatments is consistent with the idea that carotenoids are generally more likely to pass through invertebrates undigested than chl a and are therefore more likely to be deposited (McLeroy-Etheridge \& McManus, 1999).

In contrast, in mussel tanks from the lake system, pigment concentrations increased about 10-20-fold, an effect that was positively correlated with mussel size. We suggest that this vast increase in phytoplankton concentration could be due to a particularly strong $\mathrm{N}$-fertilisation effect by mussel excretion, which averaged about $50 \mu \mathrm{g}$ TAN $\mathrm{l}^{-1} \mathrm{~h}^{-1}$ in the lake laboratory experiment, and which was also positively correlated with mussel size. In the experimental density of 1 mussel $31^{-1}$, this might lead to phytoplankton growth rates that are faster than clearance rates of mussels. An alternative or additional 
Lake Sinanodonta woodiana

(a) $\mathrm{chl} \mathrm{a}$

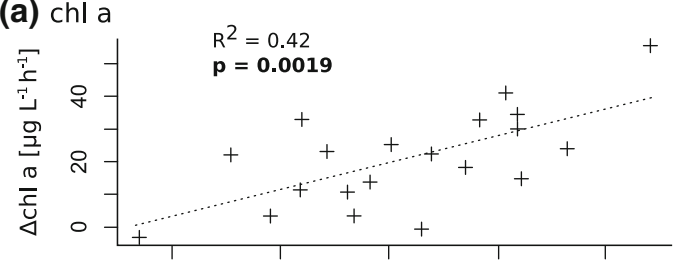

(b) carotenoids

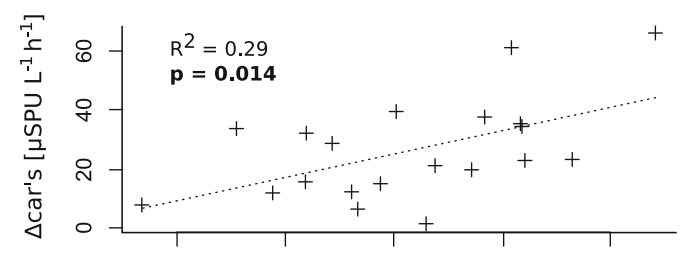

\section{(c) PP}

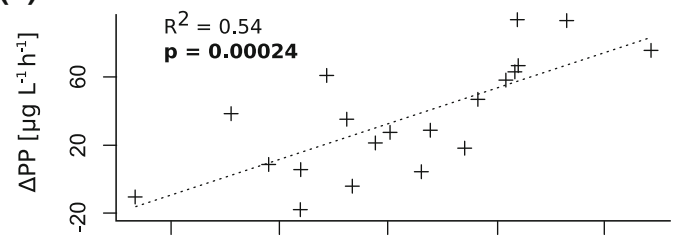

(d) SRP

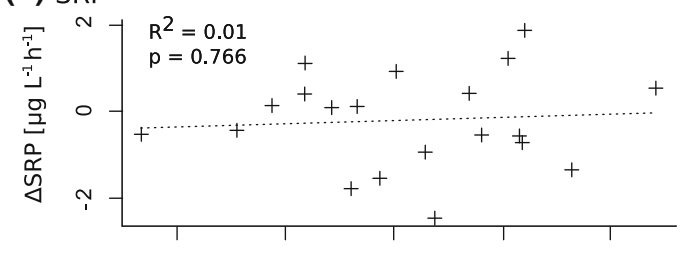

(e) TAN

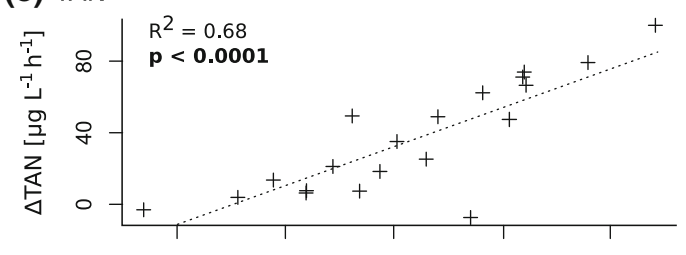

(f) $\mathrm{NO}_{3}-\mathrm{N}$

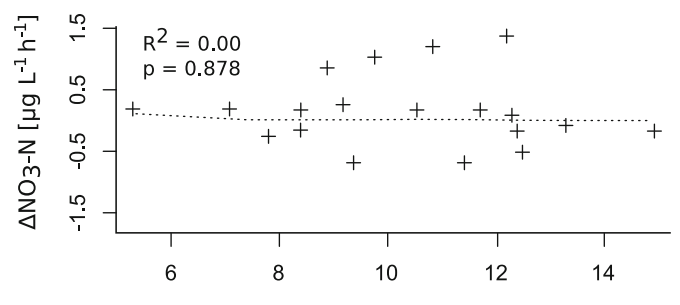

Mussel shell length $[\mathrm{cm}]$
- River Contradens contradens

- River Monodontina vondembuschiana
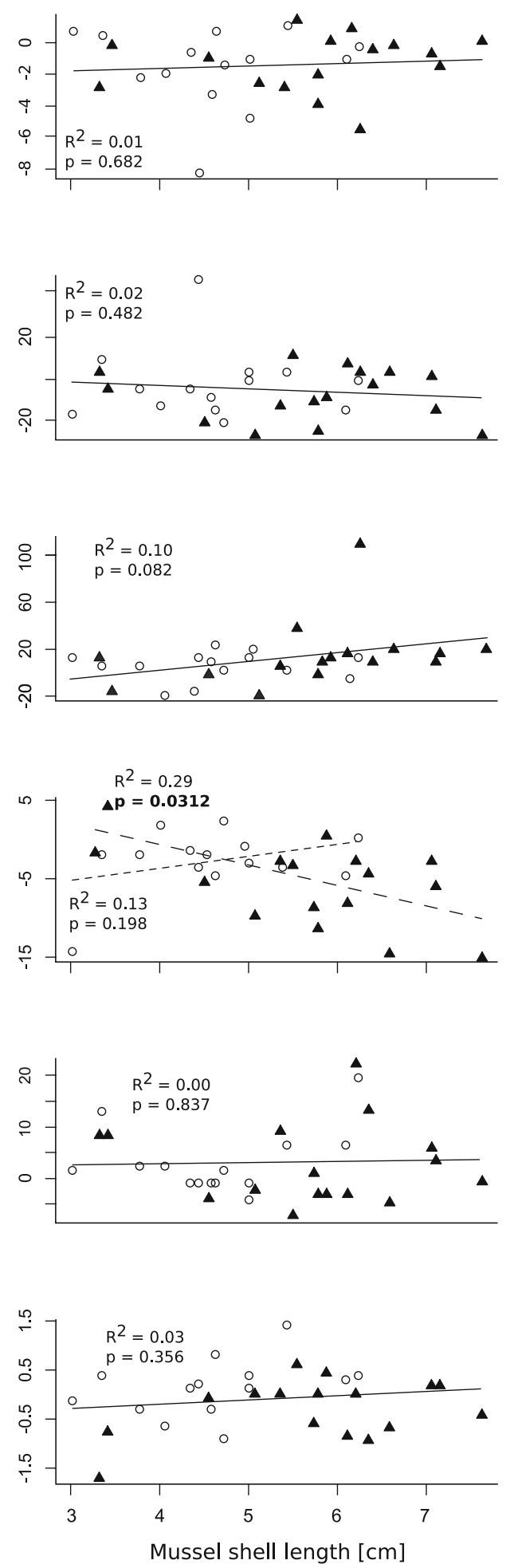
4 Fig. 3 Relationship between mussel shell length and change in pigment and nutrient concentrations per species after $3 \mathrm{~h}$ in 31 of lake or river water. Bold values are significant at $95 \%$ level

explanation for the observed increase in photosynthetic pigments in lake-mussel tanks could be bioseston material that was present in the digestive system of lake mussels at the time of collection, and was released as (partly) undigested bioseston during the experimental period. Selective feeding and ejection of different phytoplankton taxa has been observed in Sinanodonta calipygos (Kobelt, 1879) from Lake Biwa, which was shown to preferentially feed on small algae $<10 \mu \mathrm{m}$ in size (e.g., Scenedesmus, Selenastrum and Synechococcus), whilst large species were rejected (e.g., Aphanocapsa, Pediastrum spp.) (Miura \& Yamashiro, 1990). Similar processes might be important in the closely related $S$. woodiana in the eutrophic Lake Semenyih. As our experimental design did not allow for discrimination between bioseston in the water column and deposited bioseston, we are unfortunately unable to accurately quantify the relative contribution of each of these components.

\section{Clearance rates}

In the field experiments, seston $\Delta \mathrm{chl}$ a and $\Delta$ carotenoids were significantly negatively correlated with mussel density and biomass at both sites. This indicates that freshwater mussels are clearing phytoplankton from the water column, with more mussels clearing a larger proportion of the water volume, as has been observed in a number of previous experiments (e.g., Soto \& Mena, 1999; Chowdhury et al., 2016; Douda \& Čadková, 2018).

Clearance rates (CRs) calculated from laboratory experiments for both river species were relatively high, averaging 0.8-1 1 mussel $^{-1} \mathrm{~h}^{-1}$ and reaching over 31 mussel $^{-1} \mathrm{~h}^{-1}$ in $M$. vondembuschiana. These values exceed most previously published freshwater mussel laboratory filtration rates that were measured in tanks under static conditions, without sediment and using cultured algae or water taken from a different source than the study population. For example, previously reported CRs from other freshwater mussel populations of similar average sizes $(\sim 5 \mathrm{~cm}$ SL) averaged $0.1-0.71$ mussel $^{-1} \mathrm{~h}^{-1}$ in different lentic and lotic species of North America (Byllaardt \&
Ackerman 2014); 0.31 mussel $^{-1} \mathrm{~h}^{-1}$ in Parreysia caerulea Lea, 1831/Lamellidens marginalis (Lamarck, 1819) from a eutrophic lake in Bangladesh (Chowdhury et al., 2016), and 0.5-0.7 1 mussel $^{-1}$ $\mathrm{h}^{-1}$ in Echyridella menziesi (Gray, 1843) from six oligo- and mesotrophic lakes in New Zealand (Cyr et al., 2017). Our values were, however, comparable to those measured by Kryger \& Riisgård (1988) in a more natural circumstances using sediment-containing aquaria, with a single-species algal culture. The reason for the comparatively high filtration rates observed in the present study might be that we used water from the mussels' natural habitat and conducted experiments at a slightly higher temperature $\left(25^{\circ} \mathrm{C}\right)$ compared to most previous studies $\left(19-21^{\circ} \mathrm{C}\right)$. Nevertheless, we argue that observed filtration rates were still likely underestimations for a number of reasons: (1) mussels are likely to have been disturbed by the sampling process; (2) water temperatures in the lake and river site usually exceed $25^{\circ} \mathrm{C}$ (A. Zieritz, unpublished data); (3) our experimental design does not distinguish between chl a not ingested from the water column and chl a ingested and deposited to the water column. Finally, (4) Byllaardt \& Ackerman (2014) showed that compared to static conditions, freshwater mussel CR (of algae measured with a fluorometer) under continuous supply of algae (algal flux) in a recirculating flowchamber increases by an average of 20 and up to over 40 times, especially for riverine species. High CRs in flow-through chambers were confirmed by Douda \& Čadková (2018) on S. woodiana from Kyjovka River, Czech Republic, measuring an average filtration rate of about 2.51 per mussel. Future studies on tropical river mussels should thus be conducted under more natural flow conditions using river mesocosms or flow chambers.

Due to the observed increase in chl a in lake laboratory experiments (see above for a discussion of potential reasons for this observation), clearance rates could not be calculated for lake mussels.

\section{Conclusions}

Our study indicates that the effects of mussels on nutrient cycling and bioseston growth can differ considerably between tropical freshwater ecosystems, depending on nutrient availability in the system, and excretion rates and filtration ability of the mussel 
community. Excretion by mussels probably accelerated bioseston growth in both systems due to $\mathrm{N}$-fertilisation, an effect that may be particularly common in tropical freshwaters, which are frequently N-limited. However, whilst river mussels reduced bioseston concentrations through rapid filtration, higher rates of N-excretion and/or deposition of undigested bioseston by lake mussels apparently resulted in a netincrease of pigment concentrations. Further experiments are required to assess whether these results can be generalized across tropical river and lake systems, and whether the observed differences are triggered by differences in the environmental conditions at the sites, a species-effect or a combination of the two. Answering the question whether non-native and native species play different functional roles in the same ecosystem will be particularly important considering the fast and ongoing spread of S. woodiana across Southeast Asia and beyond (Zieritz et al., 2016, 2018a, b).

Acknowledgements This study was supported by grants of the Malaysian Ministry of Higher Education (FRGS/1/2015/ WAB13/UNIM//1) and the Malacological Society of London (Research Grant) to AZ. T Needham, SNKC Samsuddin and V Panizzo assisted with laboratory work. K Nkonda and DAVA Wanigasekara assisted with fieldwork.

Open Access This article is distributed under the terms of the Creative Commons Attribution 4.0 International License (http:// creativecommons.org/licenses/by/4.0/), which permits unrestricted use, distribution, and reproduction in any medium, provided you give appropriate credit to the original author(s) and the source, provide a link to the Creative Commons license, and indicate if changes were made.

\section{References}

Atkinson, C. L., C. C. Vaughn, K. J. Forshay \& J. T. Cooper, 2013. Aggregated filter-feeding consumers alter nutrient limitation: consequences for ecosystem and community dynamics. Ecology 94: 1359-1369.

Baker, S. M. \& D. J. Hornbach, 2001. Seasonal metabolism and biochemical composition of two unionid mussels, Actinonaias ligamentina and Amblema plicata. Journal of Molluscan Studies 67: 407-416.

Byllaardt, J. \& J. D. Ackerman, 2014. Hydrodynamic habitat influences suspension feeding by unionid mussels in freshwater ecosystems. Freshwater Biology 59: 1187-1196. https://doi.org/10.1111/fwb.12339.

Chowdhury, G. W., A. Zieritz \& D. C. Aldridge, 2016. Ecosystem engineering by mussels supports biodiversity and water clarity in a heavily polluted lake in Dhaka, Bangladesh. Freshwater Science 35: 188-199.

Christian, A., B. Smith, D. Berg \& J. Smoot, 2004. Trophic position and potential food sources of 2 species of unionid bivalves (Mollusca: Unionidae) in 2 small Ohio streams. Journal of the North American Benthological Society 23: $101-113$.

Collier, K. J., S. J. Clearwater, P. H. M. W. Neijenhuis, \& S. A. Wood, 2017. Factors influencing biodeposit production by the New Zealand freshwater mussel Echyridella menziesii. New Zealand Journal of Marine and Freshwater Research Taylor \& Francis 1-15, https://www.tandfonline. com/doi/full/10.1080/00288330.2017.1307234.

Cumberlidge, N., P. K. L. Ng, D. C. J. Yeo, C. Magalhães, M. R. Campos, F. Alvarez, T. Naruse, S. R. Daniels, L. J. Esser, F. Y. K. Attipoe, F.-L. Clotilde-Ba, W. Darwall, A. McIvor, J. E. M. Baillie, B. Collen \& M. Ram, 2009. Freshwater crabs and the biodiversity crisis: importance, threats, status, and conservation challenges. Biological Conservation 142: 1665-1673.

Cunha, D. G. F., M. do C. Calijuri \& M. C. Lamparelli, 2013. A trophic state index for tropical/subtropical reservoirs (TSItsr). Ecological Engineering 60: 126-134.

Cyr, H., K. J. Collier, S. J. Clearwater, B. J. Hicks \& S. D. Stewart, 2017. Feeding and nutrient excretion of the New Zealand freshwater mussel Echyridella menziesii (Hyriidae, Unionida): implications for nearshore nutrient budgets in lakes and reservoirs. Aquatic Sciences 79: 557-571.

Dodds, W. K., J. R. Jones \& E. Welch, 1998. Suggested classification of stream trophic state: distributions of temperate stream types by chlorophyll, total nitrogen, and phosphorus. Water Research 32: 1455-1462.

Douda, K. \& Z. Čadková, 2018. Water clearance efficiency indicates potential filter-feeding interactions between invasive Sinanodonta woodiana and native freshwater mussels. Biological Invasions 20: 1093-1098.

Downing, J. A., M. Mcclain, R. Twilley, J. M. Melack, J. Elser, N. N. Rabalais, W. M. Lewis, R. E. Turner, J. Corredor, D. Soto, A. Yanez-Arancibia, J. A. Kopaska \& R. W. Howarth, 1999. The impact of accelerating land-use change on the $\mathrm{N}$-cycle of tropical aquatic ecosystems: current conditions and projected changes. Biogeochemistry 46: 109-148.

Dudgeon, D., A. H. Arthington, M. O. Gessner, Z. Kawabata, D. Knowler, C. Lévêque, R. J. Naiman, A. H. Prieur-Richard, D. Soto, M. L. J. Stiassny \& C. A. Sullivan, 2006. Freshwater biodiversity: importance, status, and conservation challenges. Biological Reviews 81: 163-182.

Graf, D. L. \& K. S. Cummings, 2015. The Freshwater Mussels (Unionoida) of the World (and other less consequential bivalves), updated 5 August 2015. MUSSEL Project Web Site., http://mussel-project.uwsp.edu/.

Howard, J. K. \& K. M. Cuffey, 2006. The functional role of native freshwater mussels in the fluvial benthic environment. Freshwater Biology 51: 460-474.

James, M., 1987. Ecology of the freshwater mussel, Hyridella menziesi (Gray) in a small oligotrophic lake. Archiv fuer Hydrobiologie 108: 337-348.

Kryger, J. \& H. U. Riisgård, 1988. Filtration rate capacities in 6 species of European freshwater bivalves. Oecologia 77: 34-38. 
Lewis, W. M., 2001. Causes for the high frequency of nitrogen limitation in tropical lakes. SIL Proceedings 1922-2010(28): 210-213.

Lorenzen, C. J., 1967. Determination of chlorophyll and pheopigments: spectrophotometric equations. Limnology and Oceanography 12: 343-346.

Mackereth, F. J. H., J. Heron \& J. F. Talling, 1989. Water Analysis: some Revised Methods for Limnologists. Freshwater Biological Association Special Publication, Ambleside.

McIvor, A., 2004. Freshwater Mussels as Biofilters. Department of Zoology, University of Cambridge, Cambridge.

McLeroy-Etheridge, S. L. \& G. B. McManus, 1999. Food type and concentration affect chlorophyll and carotenoid destruction during copepod feeding. Limnology \& Oceanography 44: 2005-2011.

Miura, T. \& T. Yamashiro, 1990. Size selective feeding of Anodonta calipygos, a phytoplanktivorous freshwater bivalve, and viability of egested algae. Japanese Journal of Limnology 51: 73-78.

Nalepa, T. F., W. S. Gardner \& J. M. Malczyk, 1991. Phosphorus cycling by mussels (Unionidae: Bivalvia) in Lake St Clair. Hydrobiologia 219: 230-250.

Nichols, S. \& D. Garling, 2000. Food-web dynamics and trophic-level interactions in a multispecies community of freshwater unionids. Canadian Journal of Zoology 78 : 871-882.

Raikow, D. F. \& S. K. Hamilton, 2001. Bivalve diets in a midwestern U.S. stream: a stable isotope enrichment study. Limnology and Oceanography 46: 514-522.

Riisgård, H. U., 2001a. On measurement of filtration rates in bivalves - the stony road to reliable data: review and interpretation. Marine Ecology Progress Series 211: 275-291.

Riisgård, H. U., 2001b. The stony road to reliable filtration rate measurements in bivalves: a reply. Marine Ecology-Progress Series Inter Research 215: 307-310.

Ruxton, G. D., 2006. The unequal variance t-test is an underused alternative to Student's t-test and the Mann-Whitney $U$ test. Behavioral Ecology 17: 688-690. https://doi.org/10. 1093/beheco/ark016.

Saraiva, S., J. Van Der Meer, S. Kooijman \& T. Sousa, 2011. Modelling feeding processes in bivalves: a mechanistic approach. Ecological Modelling 222: 514-523.

Soto, D. \& G. Mena, 1999. Filter feeding by the freshwater mussel, Diplodon chilensis, as a biocontrol of salmon farming eutrophication. Aquaculture 171: 65-81.

Spooner, D. E. \& C. C. Vaughn, 2006. Context-dependent effects of freshwater mussels on stream benthic communities. Freshwater Biology 51: 1016-1024.

Spooner, D. E. \& C. C. Vaughn, 2008. A trait-based approach to species' roles in stream ecosystems: climate change, community structure, and material cycling. Oecologia 158: 307-317.

Vaughn, C. C., 2018. Ecosystem services provided by freshwater mussels. Hydrobiologia 810: 15-27.

Vaughn, C. C., K. B. Gido \& D. E. Spooner, 2004. Ecosystem processes performed by unionid mussels in stream mesocosms: species roles and effects of abundance. Hydrobiologia 527: 35-47.

Vaughn, C. C., D. E. Spooner \& H. S. Galbraith, 2007. Context dependent species identity effects within a functional group of filter-feeding bivalves. Ecology 88: 1654-1662.

Vaughn, C. C., S. J. Nichols \& D. E. Spooner, 2008. Community and foodweb ecology of freshwater mussels. Journal of the North American Benthological Society 27: 409-423.

Watters, G. T., 1997. A synthesis and review of the expanding range of the Asian freshwater mussel Anodonta woodiana (Lea, 1834) (Bivalvia, Unionidae). The Veliger 40: 152-156.

Welker, M. \& N. Walz, 1998. Can mussels control the plankton in rivers? A phytological approach to Lagrangian sampling strategy. American Society of Limnology and Oceanography 43: 753-762.

Winemiller, K. O. \& D. B. Jepsen, 2005. Effects of seasonality and fish movement on tropical river food webs. Journal of Fish Biology 53: 267-296.

Zhang, H., X. Yu, Y. Wang \& J. Xu, 2017. The importance of terrestrial carbon in supporting molluscs in the wetlands of Poyang Lake. Chinese Journal of Oceanology and Limnology 35: 825-832. https://doi.org/10.1007/s00343-0176014-8.

Zieritz, A., M. Lopes-Lima, A. E. Bogan, R. Sousa, S. Walton, K. A. A. Rahim, J.-J. Wilson, P.-Y. Ng, E. Froufe \& S. McGowan, 2016. Factors driving changes in freshwater mussel (Bivalvia, Unionida) diversity and distribution in Peninsular Malaysia. Science of the Total Environment 571: 1069-1078.

Zieritz, A., A. E. Bogan, E. Froufe, O. Klishko, T. Kondo, U. Kovitvadhi, S. Kovitvadhi, J. H. Lee, M. Lopes-Lima, J. M. Pfeiffer, R. Sousa, T. van Do, I. Vikhrev \& D. T. Zanatta, 2018a. Diversity, biogeography and conservation of freshwater mussels (Bivalvia: Unionida) in East and Southeast Asia. Hydrobiologia 810: 29-44.

Zieritz, A., A. E. Bogan, K. A. A. Rahim, R. Sousa, L. Jainih, S. Harun, N. F. A. Razak, S. McGowan, R. Hassan \& M. Lopes-Lima, 2018b. Changes and drivers of freshwater mussel diversity and distribution in northern Borneo. Biological Conservation 219: 126-137.

Publisher's Note Springer Nature remains neutral with regard to jurisdictional claims in published maps and institutional affiliations. 